\title{
The rise of China between Global IR and area studies: an agenda for cooperation
}

\author{
Matteo Dian* (D) \\ University of Bologna, Bologna, Italy \\ ${ }^{*}$ Corresponding author. Email: matteo.dian2@unibo.it
}

(Received 2 February 2021; revised 20 July 2021; accepted 21 July 2021; first published online 16 August 2021)

\begin{abstract}
East Asia is increasingly at the centre of debates among International Relations (IR) scholars. China's political, economic, and military ascendency is increasingly considered as a crucial test case for main approaches to IR. Despite this renewed attention, mainstream theories employed to analyse contemporary Asia are still remarkably Euro-centric. A wave of studies has argued in favour of a broad 'decolonization' of theoretical concepts used to analyse East Asia as well as other regions. These efforts have produced several distinct research agendas. Firstly, critical and post-colonial theorists have worked on the par destruens, highlighting the inherent Euro-centrism of many IR concepts and theories. Secondly, scholars such as Buzan and Acharya have promoted the idea of Global IR, seeking to advance a 'non-Western' and non-Euro-centric research agenda. This agenda has found fertile ground especially in China, where several scholars have tried to promote a Chinese School of IR. This article has three main purposes. Firstly, it briefly explores the issue of Eurocentrism in IR studies dedicated to East Asia. Secondly, it maps the theoretical debates aimed at overcoming it, looking in particular at the 'Global IR' research programme and the so-called Chinese School. Finally, it sketches a few other possible avenues of research for a very much needed cooperation between Global IR and area studies.
\end{abstract}

Key words: Area studies; Chinese School of IR; Eurocentrism; Global IR; non-Western IR theory; rise of China

\section{Introduction}

During the last decade, the rise of China and the global power shift towards East Asia have become a central focus for International Relations (IR) scholarship (Cox, 2012; Vezirgiannidou, 2013). The rise of China, in particular, has been considered as a new battleground for different approaches to IR. Other key developments in the region have entered the forefront of the theoretical discussion in the discipline. Examples are developments of different forms of economic and political regionalism, evolution of the alliance relations, forms of cooperation in the field of non-traditional security, just to mention a few.

This article, coherently with the rest of the Special Issue 'Reaching for allies? The dialectics and overlaps between International Relations and Area Studies in the study of politics, security and conflicts', aims at promoting a critical reflection on how IR theory as a discipline approaches these topics, and how, while doing it, engages with area studies and cognate disciplines. More specifically, this article has three main purposes. Firstly, it explores the issue of Eurocentrism in IR studies dedicated to East Asia. Secondly, it maps the theoretical debates aimed at overcoming it, looking in particular at the 'Global IR' research programme and the so-called Chinese School. Doing so, the article aims at contributing to the debate promoted by this Special Issue on how to bridge the divide between IR and area studies (see Introduction). In particular, this

(C) The Author(s), 2021. Published by Cambridge University Press on behalf of the Società Italiana di Scienza Politica. This is an Open Access article, distributed under the terms of the Creative Commons Attribution licence (http://creativecommons.org/licenses/by/4.0/), which permits unrestricted re-use, distribution, and reproduction in any medium, provided the original work is properly cited. 
article aims at demonstrating that the emergence and the development of post-Western theoretical approaches represent a valuable opportunity to overcome several blindspots characterizing positivist and mainstream approaches to IR, especially when it comes to the study of East Asia. The article also highlights several limits these approaches might entail. The most evident appears to be a tendency to essentialism and a limited capacity of theories and approaches to 'travel', namely, to explain different cases. ${ }^{1}$ The Chinese School in particular tends to 'speak for power', producing concepts and analyses that can be considered functional to legitimate the political narrative promoted by the Chinese government. In this sense, the Chinese School is affected by some of the same problems post-colonial and theorists identify in mainstream theories. Finally, the article sketches a few other possible avenues of research for a very much needed cooperation between Global IR and area studies. More specifically, the article stresses the need to broaden the conceptual and historical horizons of IR theory, including cases and samples associated with a wider geographical and historical spectrum. This is not only functional to the possibility of collecting new data. It is necessary to reconsider the conceptual and theoretical limits of certain categories that are deemed as universal and natural, such as state, sovereignty, anarchy, market, or international order. On the one hand, this process would be useful for the discipline to grow out of some of its Euro-centric bias and its limited engagement with non-Western regions. On the other hand, it would represent an alternative to current assumptions associated with the critical and post-Western theories as the emphasis on deconstruction and the promotion of 'national approaches'. The latter often leads to assume that the behaviour of each country is exceptional and incommensurable and can be understood only referring to local conditions and local concepts, foreclosing possibilities for comparison as well as theoretical and analytical progresses.

\section{The rise of China and Eurocentrism in IR}

Despite the renewed attention to the case of the rise of China, mainstream theories employed to analyse contemporary Asia are still remarkably Euro-centric. A notable example is the Graham Allison's book Destined for War, in which, the author compares ancient Athens and Sparta and other 16 cases of power transition, in order to advance a hypothesis on the future of USChina relations. Most of the selected cases regard modern or contemporary Europe, or the US and the USSR (Allison, 2017). As Kang has pointed out, from Allison's perspective, 'nothing that happened in Asia over the past 2500 years, or elsewhere in the world, for that matter, that is important enough to study' (Kang, 2017).

Kang's criticism points to an obvious weakness of IR theory: the majority of mainstream approaches have been derived by and tested on European or Trans-Atlantic history. Then it has been simply assumed that those theories are characterized by what Robert Gilpin called 'timeless wisdom' and applied, and often misapplied, to other regional contexts (Gilpin, 1984).

Clearly, the history of other regions, or the study of the comparative evolution of non-Western international systems, has been rarely used by IR scholars to produce and test their theories. A prominent example of this logic is the comparison made by Aaron Friedberg between post-Cold War Asia and Europe in the 1930s. Friedberg, involuntarily displaying the Euro-centric bias of his reasoning, titled a 2000 Survival piece 'Will Asia's future be Europe's past?' (Friedberg, 2000). Predictably, that article attracted the criticism of many scholars who underlined how many assumptions drove the comparison: the centrality of Western history for IR, the assumption of history as a cycle, and the general lack of focus on non-Western history (Kang, 2003; Acharya, 2004; Hurrell, 2016; Kang and Lin, 2019).

A complete and exhaustive discussion of the Euro-centric bias in contemporary and classic IR is surely beyond the space and the scope of this article. However, it is significant to mention a few

\footnotetext{
${ }^{1}$ Sartori (1970) argued concepts able to 'travel', explaining different cases in different times, are the building blocks of political and social sciences.
} 
of the crucial concepts that at a close scrutiny immediately reveal their Euro-centric bias (Hobson, 2012).

The first is the 'myth of Westphalia' (Osiander, 2001; Teschke, 2003). The peace of Westphalia is generally considered a benchmark date for the foundation of the contemporary sovereign state as well for the contemporary international system or international society. Realists have generally assumed that every state in every historical configuration behaves 'like units', in an equalitarian system, without functional differentiation, while maximizing their security or power (Waltz, 1979). As Kenneth Waltz stated, 'the enduring anarchic character of international politics accounts for the striking sameness in the quality of international life through the millennia' (Ibidem). Despite recognizing the historical presence of different forms of international systems, he argues that 'international-political systems, like economic markets, are individualist in origin, spontaneously generated, and unintentional' (Ibidem).

The centrality of the Westphalian peace as a foundational benchmark for IR has been alimented also by other approaches. Constructivists such as Wendt and Jackson have argued that 1648 was a significant shift for international politics. According to Wendt, the Peace of Westphalia represented one of the very few crucial passages between Hobbesian and Lockean type of anarchy and the development of some forms of mutual recognition between states (Wendt, 1999). Non-European or non-Western international systems do not appear in Wendt's framework, or at least implicitly they are supposed to conform to this trajectory.

The 'classic' English School, traditionally keener to historical research, has studied the interaction between the West and the rest theorizing the expansion of the European International Society, explaining how other regions of the world absorbed the primary institutions of the Westphalian European society of states, such as sovereignty, balance of power, diplomacy, and international law (Bull and Watson, 1984). The contemporary English School has significantly reconsidered the theory of the expansion of the international society, amending it from its Euro-centric features and including a much more balanced and nuanced account of the often brutal encounter between West and East in the colonials era (Suzuki, 2009; Buzan and Lawson, 2014, 2015).

In general, however, IR theory tends to assume that any state would behave as a modern Westphalian state. All states should have therefore similar rights and duties, they should not recognize any superior or inferior political entity, and they should conform to the 'laws' of balance of power or hegemony.

The Westphalian myth leads to several problems for the discipline: it distorts our understanding of the emergence of the modern international system; it leads to misinterpretation of major aspects of contemporary IR; it prevents from theorizing cross-regional interactions and it thwarts the accommodation of pluralism in an increasingly globalized world (Kayaoglu, 2010).

Another significant issue is the lack of agency for the non-Western world. When non-Western states and people are included in theoretical accounts, they tend to be passive and 'without agency': depending on the perspective in which they were socialized, included, 'civilized', absorbed, or colonized. They did not act in the process. They simply appeared in the picture and, consequently in the discipline's theoretical accounts, when they started to interact, often in a very asymmetric way, with Western powers.

As underlined by Evelyn Goh, American IR, with its preference for positivism, has contributed to this bias. On the one hand, the preference for positivist approaches and the search for 'covering laws' has promoted a 'hyper-westernized framework of cognitive biases and normative assumptions', regarding states' behaviour, stability of the system, balance of power, the nature of the international order, as well as epistemological assumptions the alleged neutrality of the knowledge produced by IR scholars (Goh, 2019).

Ultimately what appears clear is that different approaches in the discipline and in particular structural realism, but also 'mainstream' constructivism, have approached Asia with theoretical 
instruments, concepts, and research agendas largely drawn from the European or at best Trans-Atlantic history and with a methodological and epistemological approach strongly shaped by the American hegemony in political science and IR.

The next section of the paper will engage with criticism offered to this problem and possible solutions offered by critical IR, and promoters of the 'Global IR' or 'non-Western IR' schools.

\section{Post-colonial, non-Western, and Global IR}

A wave of studies has argued in favour of a broad 'decolonization' of theoretical concepts used to analyse East Asia. This effort has produced several distinct research agendas. Firstly, critical and post-colonial theorists have worked on the par destruens, highlighting the inherent Euro-centrism of many IR concepts and theories. Secondly, authors such as Buzan and Acharya have promoted the idea of Global IR, seeking to advance a 'non-Western' research agenda. This agenda has found fertile ground especially in China, where several scholars have tried to promote a Chinese School of IR.

Critical and post-colonial theorists have been at the forefront of the effort to criticize the Euro-centric bias of many theoretical assumptions and approaches (Hobson, 2012; Hobson and Sajed, 2017). On the one hand, critical theories have pointed out how mainstream approaches cannot be considered as neutral but should rather be considered as expression of the perspective of their authors and the social, economic, and political forces in which they live and write. In other words, against positivism, no social theory can express a neutral point of view, but rather a biased, contingent, and socially and politically located perspective, informed by the hegemonic forces shaping a given system (Tickner, 2003). As Robert Cox has argued: 'there is no such thing as theory in itself, divorced from a standpoint in time and space. When any theory so represents itself, it is the more important to examine it as ideology, and to lay bare its concealed perspective' (Cox, 1987). From this point of view, possibly with a bit of exaggeration, much of mainstream IR appears to be an expression of US and Western material and ideological hegemony, rather than the result of neutral and unbiased scholarship aiming at discovering the inner workings of international politics (Cox, 1983; Gill, 1993; Hopf, 2013). Therefore, theories such as the hegemonic stability theory (or its liberal variants, à la Ikenberry), for instance, would be considered as a form of legitimation for the US hegemony (Seth, 2009). Moreover, critical theory aims at denouncing the 'technical reason' dominant in mainstream IR (Neufeld, 1995) and its conservative bias, trying to avoid, in the words of Kimberly Hutchins, 'reproduce the patterns of hegemonic power of the present' (Hutchings, 2021).

Building on these positions, critical theorists have highlighted the necessity to understand the role of hegemonic intellectual forces in the development of IR as a discipline, consider multiple empirical and theoretical points of view, and the relative nature of many epistemological assumptions.

Post-colonial theorists have built on these assumptions putting forward several key arguments:

1. The notion of 'neo-colonialism', namely the idea that post-colonial states have developed different forms of dependence from the West or, more specifically, their former colonial powers that can vary from psychological, social, technological, and economic (Sajed, 2013; Tickner, 2013; Persaud and Sajed, 2018).

2. The rejection of the idea that modernity has been developed in Europe to be exported in other areas of the world, to be replaced by the concept that modernity has developed through the interaction between the West and the colonial world, through forms of global interaction (Chakrabarty, 2000; Buzan and Lawson, 2015).

In this sense, the post-colonial approach seeks, as Sanjay Seth put it, to 'provincialize Europe', in three different ways. Firstly, it challenges the centrality accorded to Europe as the historical 
source and origin of the international order; secondly, it questions the universality accorded to moral and legal perspectives which reflect and reproduce the power relations characteristic of the colonial encounter; finally, it underlines the constitutive role of knowledge in IR, reminding how concepts and representations shape political categories and practices (Seth, 2011).

3. The renewed significance given to the interaction between core and periphery in the development of modernity (Pomeranz, 2000; Buzan and Lawson, 2015). From this point of view, the core-periphery relationship is a crucial constituent of the contemporary international system as much as anarchy and distribution of power. In particular, the development of technology, the industrial revolution, and the rise of capitalist modernity have turned separate regional orders into a global international order that encompassed elements of parity among states as well as elements of hierarchy between the core and the periphery of the system. In this sense, in the words of Persaud and Sajed, 'The Third World has been a maker of the international system as much as it has been made by it' (Persaud and Sajed, 2018).

4. The fact that the patterns of inclusion/exclusion, subordination, socialization, and adaptation have decisively shaped the course of the political development of key non-European States such as Turkey, Japan, and Russia (Zarakol, 2010). The hierarchical and racialized nature of the international order developed between the XIX and the XX, determined by the expansion of the European international society, has fundamentally influenced the interaction between the West and the key non-Western powers. This element is crucial both to understand those states' choices in the past and their legacy, but also how non-Western powers perceive the contemporary international order and their role within it.

5. The rejection of the idea that IR should be, following Waltz, about 'few important things' and about 'great powers'. On the contrary, post-colonial theorists highlight the necessity to look at the role of 'subjects and powerless' and their perspective, in order to provide an account of the role and the perceptions of actors that are different from great powers and economic and political elites. This, in turn, entails both a criticism of mainstream approaches as well as a different angle of observation to the objects of the scholarly analysis. This argument implies the recognition of multiple forms of normative agency associated with non-Western states and non-hegemonic ideas and norms (Acharya, 2014).

These arguments and these assumptions contributed to the approach labelled 'Global IR' or 'non-Western IR' promoted mainly by Barry Buzan and Amitav Acharya (Acharya and Buzan, 2007, 2019). This project aimed at searching for new intellectual resources that could originate in non-Western theories of IR. In particular, they sought to: survey the thinking about IR theory in the non-Western countries; discuss whether it has been excluded from the Western debates; examine the historical, political, and philosophical resources of the country/area concerned with an evaluation of how these do or don't play into the debates about IR theory; and assess how they might form the basis of an indigenous non-Western IR theory. Finally, assessing how the key Western IR concepts such as sovereignty, statehood, legitimacy, balance of power, great power fit or don't fit with local traditions and practices.

This project was built on the necessity to overcome Eurocentrism in IR and welcoming the idea that theories are not neutral but are conditioned by the context in which they have been elaborated, while they refrain from considering IR theories as expression of intellectual hegemony. As Acharya has argued, 'the main theories of IR are too deeply rooted in, and beholden to, the history, intellectual traditions, and agency claims of the West, to accord little more than a marginal place to those of the non-Western world' (Acharya, 2016: 8). Therefore, they argue that the discipline needs to develop a more plural approach built on different regional and national schools. 


\section{The Chinese School and its limits}

Chinese scholars, within the country as well as outside, are those who took the idea of non-Western theory and 'national' theories of IR more seriously. The Chinese School of IR have emerged in the last 10 or 15 years $^{2}$ with the works of IR theorists such as Qin Yaqing (Qin, 2006, 2007) and Yan Xuetong ${ }^{3}$ (Yan, 2011, 2014, 2020), and the philosopher Zhao Tingyang (Zhao, 2006, 2009).

The Chinese School has received a significant attention also outside the Chinese academia, generating a debate that has involved scholars such as Barry Buzan, William Callahan, Astrid Nordin, and Linus Hagström (Callahan, 2008; Wang and Buzan, 2014; Nordin, 2016; Hagström and Nordin, 2019).

The key insight of the first three was the idea of re-founding the main concepts and approaches to IR departing from ancient Chinese thinking, especially from the pre-Qing era. As a consequence, they drew on classic authors such as Confucius primarily, but also Laozi and Mencius, as well as Daoist philosophy. This attempt to ground a new theoretical approach somehow mirrored the fact that contemporary realism is based on concepts originally put forward by Western classical political thinkers such as Thucydides, Hobbes, and Machiavelli.

Within the Chinese School, it is possible to identify two distinct contributions. The first looks at Confucian concepts such as harmony and hierarchy, associated with Yan Xuetong and Zhao Tingyang's contributions, and the idea of relationality, promoted mainly by Qin Yaqing.

The concept of harmony (hexie) refers to the possibility and the necessity of finding an agreement between different positions and different values, without resorting to conflict and violence. The condition of harmony does not entail homogeneity, but the possibility of coexistence between differences. The Confucian tradition also contributes to a substantial re-evaluation and reconsideration of the political order generated by the Chinese Empire. As Yan Xuetong has argued, historically the Chinese world order was based on 'humane authority' (wang), rather than on hegemony $(b a)$. As he stated: 'The root difference between humane authority and hegemonic authority is that the former relies on morality and the latter on material power to uphold interstate order' (Yan, 2011). The stability of the Imperial system, as a consequence, is interpreted to be a function of morality and constraints on power, rather than on pure economic and military might.

The other key idea is that the reinterpretation of Chinese is the concept of Tianxia (all under heaven). Both classic and more recent literature in the fields of Chinese history and IR theory have discussed extensively whether and how the idea of Tianxia, and the Sino-centric world order, represented an accurate representation of the reality of Asia before the age of imperialism, or if those concepts reflected an ideological construction to legitimize the Chinese imperial power, or even if they were simply a historical myth (Fairbank and Chen, 2020; Zhang and Buzan, 2012).

The most influential contemporary reinterpretation of the Tianxia system has been proposed by the philosopher Zhao Tingyang. In this interpretation, the 'Middle Kingdom' was a benevolent empire that provided stability and prosperity through morality and moderation. This system was destroyed by Western imperialism in the 19th century (Zhao, 2006; Callahan, 2015).

Before the rise of Western imperialism, China was able to underpin a peaceful, stable, and just international order. As Zhao himself has put it:

Nearly 3000 years ago, China created a universal system that was supposed to be of-and-for the world in terms of all under heaven (Tianxia). It was designed to create the compatibility of all

\footnotetext{
${ }^{2}$ Buzan and Wang argue that the first efforts to promote a Chinese approach to IR can be traced back to the late 1980s and early 1990s with the works of Liang Shoude and Zhang Minqian in Chinese. The first significant publication in English can be considered as Qin $(2006,2007)$.

${ }^{3}$ Yan Xuetong was initially critical of the idea of a 'national' Chinese IR theory, but later contributed to the project with his Ancient Chinese thought, modern Chinese power. It is also necessary to underline that part of Yan's work is dedicated to a rather positivist approach to methods and to the analysis of US-China relations in terms that are familiar with neorealism.
} 
peoples of all nations and embodied the Chinese ideal of perpetual peace. [...] A net like world system that would create interdependence among all nations and guarantee the shared goods and benefits that were attractive to every nation in the network. The 'great harmony' of all peoples and perpetual peace were the hopeful outcomes of the Tianxia system (Zhao, 2013).

The idea of Tianxia and Sinocentic order in the Chinese debate reflects the growing awareness of and pride in the country's ancient civilization and its contribution to the world. These concepts, however, also contribute to the construction of a new form of Chinese exceptionalism (Zhang, 2013). The Tianxia system was an alternative to the Westphalian world, built on formal equality and power politics. In contrast, the Sino-centric model was rooted in Chinese superiority by virtue and morality (Dian, 2017).

The concept of Tianxia reflects a very elitist idea of how a polity and, by extension, the international order, should be governed. As Zhao himself has stated, 'most people do not really know what is best for them, but [...] the elite do, so the elite ought genuinely to decide for the people' (Zhao, 2006). This narrative creates a key moral distinction between China and the West. While the first is depicted as inherently moral and able to generate stability and harmony, the latter is portrayed as decaying, individualist, and immoral. Consequently, the Westphalian system, but also by extension the current rules-based order, should be transcended (Callahan, 2008; Zhang, 2012; Breslin, 2021).

The other contribution of the China School is related to the work of Qin Yaqing and in particular to his emphasis on relationality. Qin describes two different approaches to global governance: a rules-based approach and a relational approach and uses Europe and East Asia as case studies. According to Qin, both forms of governance exist in the contemporary international society, but the former is far more present given Western intellectual and political hegemony. Rules-based governance is considered to be shaped by the American and European tradition and post-war experience, and reflects Western individualism. Therefore, rational states are then able to interact with one another according to the various rules, institutions, and regimes that govern those relations. A relational approach, on the other hand, operates on the basis of mutual trust. This approach highlights the necessity of negotiation rather than control and predictability (Qin, 2010, 2011, 2018).

Qin's logic of relationality is rooted in the Daoist zhongyong dialectics. It stresses the role of conciliation of the opposites and complementarity over confrontation and differences. From this perspective, relations between powers, rather than being shaped by systemic constraints, are defined by processes and interactions that can lead to complementary interaction and inclusive coexistence (Qin, 2018).

The concept of relationality is central also to the work of LHM Ling. While she did not necessarily identify with the Chinese School, ${ }^{4}$ her work had a similar inspiration to Qin's, in terms of critique of the Western approaches and efforts to ground an alternative theory on Chinese concepts associated with the Daoist dialectic (Ling, 2018).

Liang's critique is much more radical compared with the rest of the Chinese School, since, adopting a feminist and post-colonial perspective, she sought to offer an alternative to statecentrism, violence, and permanent conflict characterizing 'Westphalian IR', with the equality, multiplicity, and hybridization between different subjects stemming from Daoist dialectic.

Overall, it can be argued that the Chinese School tends to essentialize identities, historical legacies, and cultural traits, to explain foreign policy behaviours or specific orientations in international affairs. This approach offers a substantially essentialist reading of Chinese foreign policy, stressing the causal effect of the Chinese Confucian culture (Hwang, 2021). Another, and maybe even more fundamental, problem is the risk of 'talking for power'. In doing so,

\footnotetext{
${ }^{4}$ Ling criticized the Chinese school for its paternalism and state-centrism and argued that her work seeks to promote an open, democratic, and Global IR rather than a 'Chinese IR' (Ling, 2018). Elsewhere, she argued her approach 'recognizes but not restrict itself to national schools of IR' (Ling, 2018: 27)
} 
they contribute to creating or to legitimizing a political discourse proposed by the national government or by the national elite. ${ }^{5}$ In other terms, IR theorists, especially when they conceptualize the role of a country as exceptional, can, voluntarily or not, justify the policy choices of a government. This undermines the effort to produce knowledge aimed at understanding the world. In this way, the Chinese School might be affected by the same limits many critical and poststructuralist scholars identify in 'mainstream' theories such as contemporary liberalism or the hegemonic stability theory. From this perspective, if the latter can be interpreted as the intellectual superstructure of the US hegemonic role, the Chinese School could be considered functional to justify Beijing's power and role in the world.

In the case of the Chinese School, it is hard to separate concepts that can be considered analytically useful and concepts that should be considered as functional to feed the narrative the government itself is trying to build. This is the case of concepts such as peaceful rise, peaceful development, new type of great power relations, Community of Common Destiny, and Chinese Dream (Dian, 2017; Rolland, 2020; Williams, 2021). This fusion of exceptionalism, prescription, and description appears clearly from Yan's words:

Learning from the distinction between humane authority and hegemony in pre-Qin times, the strategy for China's rise in its foreign policy should be distinct from that of the United States in three areas. First, China should promote an international order that takes as its principle a balance between responsibilities and rights. Second, China should reflect on the principle of reverse double standards, namely, that more developed countries should observe international norms more strictly than less developed ones. Third, China should promote the open principle of the traditional idea of all under heaven as one, that is, China should be open to the whole world and all the countries in the world should be open to China (Yan, 2011: 245).

Finally, so far the concepts and the theories promoted by the Chinese School seem to have problems to 'travel', namely they are not able to explain other cases, different from the Chinese case. This is surely a major shortcoming, even from the perspective of those than can be sympathetic with critical approaches to IR. Understanding the consequences of the rise of China is possibly one of the crucial aims of contemporary IR, but it cannot surely be the only possible field of applicability for any theory, even if we attach to the theory a very loose meaning and we accept the methodological and ontological arguments promoted by critical and post-modernist approaches.

As Acharya has highlighted, building generalizable concepts and theories represents the next necessary step for the Chinese School as well as for other theories associated with 'Global IR' (Acharya, 2016).

\section{Current theoretical challenges and the need for cooperation with area studies}

Cooperation between IR theory in general, and specifically Global IR, and area studies is necessary, and potentially very fruitful for both disciplines. Here I will mention a few empirical and theoretical issues that would particularly benefit from it and would contribute to the research agenda of Global IR. This would help expand the theoretical horizon of the discipline, while providing better instruments to analyse real-world political choices.

1. The necessity to expand the historical and geographical horizon of 'samples' and 'cases'. This need regards both quantitative and qualitative approaches. Research aiming at testing

\footnotetext{
${ }^{5}$ It is important to underline that Xi Jinping has called for an effort to use the Chinese wisdom and tradition to promote new Chinese solutions for global governance (Xi, 2015). While it cannot be argued that the development of the Chinese school has been directly affected by it, the 'sinification' of IR concepts is coherent with the government's objective of producing a new narrative aimed at legitimizing Beijing's great power role.
} 
theories rarely engaged with samples and cases that regard non-Western cases or non-Western history. A non-Euro-centric discipline should be able to incorporate cases from other regions of the world as well as other periods than the 19th and 20th centuries before claiming the 'universal validity' of their claims (Johnston, 2012).

At the same time, since the vast majority of IR scholars are well versed in European and Trans-Atlantic history but not in the history of other regions, it would be difficult to test theories and concepts on cases and histories of other geographical areas. This is probably another good reason to engage area studies and area scholars. This expansion of the empirical and historical horizon would not just constitute the discovery of new repository of data, against 'testing' main theories and concepts. On the contrary, it would constitute an occasion to rethink the alleged 'universal validity' of assumptions and concepts that have mainstream IR, such as anarchy, sovereign equality, the relationship between states and markets, and balance of power.

2. Overcoming the idea of the Weberian-Westphalian state as the only unit of any given international system. The idea that the system is necessarily composed of an ordinating principle (anarchy) and its units (national states) is one of the most enduring legacies of the Waltzian approach to IR. This fundamentally inhibits a sound and historically aware analysis of areas and periods in which the Weberian state was not present or fully developed or interacted with other forms of statehood and political structures. An example of the latter are recent works on British and European encounters with pre-colonial Asia, based on contacts between Western non-state agents such as the East India Company and local authorities (Bose and Horizons, 2006; Phillips and Sharman, 2015; Phillips, 2016a). These insights are functional to a number of possible progresses both for IR theory and for the dialogue with area studies and global history. Firstly, admitting the significance of non-state actors, social and political networks, and hybrid forms of political organizations different from the modern state in the encounter between Europe and the non-European world, especially in the colonial era, opens up to a significant convergence with the main purpose of contemporary global history, interested in uncovering and describing the web of social and cultural regional and global networks (Berg, 2013; Perez Garcia and De Sousa, 2018; Veevers, 2020). This helps revising the theoretical accounts of what the English School defines as the 'expansion of the international society', namely the process that has led non-Western states to adopt the main features of the Western and European international order and the Westphalian state (Bull and Watson, 1984). These emerging accounts underline that heterogeneity rather than homogeneity in terms of forms of political organizations, especially in Asia in the pre-colonial and the colonial era (Phillips, 2016b). This element in turn helps providing a more sophisticated picture of the ascendency of the West in the XIX century and its legacies for the contemporary 'rise of the East' (Buzan and Lawson, 2015)

3. The coexistence of hierarchy and anarchy. As scholars contest the theoretical necessity of the modern nation as the main actor of the international system, the debate has moved on to contest the second main assumption of the Waltzian theoretical scheme, the issue of anarchy and sovereignty equality. This has generated a number of different debates. For instance, the new hierarchy studies have investigated the possibility of considering hierarchy as an alternative organizing principle for the international order and how hierarchy affects agents' behaviour (MacDonald and Lake, 2008; Mattern and Zarakol, 2016; McConaughey et al., 2018).

Another important debate refers to the so-called 'third wave of hegemonic studies' (Ikenberry and Nexon, 2019). This research programme, trying to find a synthesis between theories on hegemony, power transition, and international order, opens new avenues of research to investigate the patterns of contestation, socialization, and resistance both at the global and regional level. 
This insight is particularly important to understand the rise of China as well as the broader process of renegotiation of the regional order in East Asia. On the one hand, the Chinese ascendency has generated a direct contestation of pre-existing hierarchies of power, status, and prestige, as well as consolidated norms. This process has in turn led to responses by other regional states, and by the US, that have sought to reaffirm and consolidate the main normative pillars of the regional order (Foot, 2019; Goh, 2019; Dian and Meijer, 2020). On the other hand, Beijing's new centrality in the region has generated new forms of hierarchies, especially in the economic sector (Li, 2019; Liu and Liu, 2021). The effects of the presence and the possible evolution of this dual hierarchy on the stability of the order, on the compliance with key norms and principles, as well as on the strategies of large and middle powers in the region are likely to be central for IR scholars and area specialists alike in the near future (Loke, 2021).

4. Investigating other pathways to modernity. IR as a discipline is remarkably anchored to several very linear stories of progress and modernity. The first is the liberal version that links the rise of capitalism and democracy within fully formed nation states, and describes it as the main 'cause' of peace. The second is the classification promoted by Alexander Wendt of the possible progress from Hobbesian, Lockean, and Kantian anarchies (Wendt, 1999). The third is the 'expansion story' promoted by the classic English School, that assumes that European states developed the main primary institutions of the international society and later on they socialized the entire world to its main rules and norms (Bull and Watson, 1984). This narrative has been integrated by the solidarist version of the English School that sees the possibility and the necessity of a further development of an international society based on primary institutions rooted on the centrality of the individual and the possibility to transcend the Westphalian features of the international society. As in the classic 'expansion' story, the process of socialization tends to go from the 'Western Core' to the 'non-Western periphery'.

These narratives at once tend to deprive non-Western actors of agency and negate the possibility of a multiplicity of pathways to modernity, limiting both the efforts to theorize how different states and regions came to terms with political, social, and economic modernity and the historical account of these processes. Moreover, in many non-Western states, the development of the nation state, the development of a capitalist economy, and the process of liberalization and inclusion of the political system did not happen in the same sequence as in Europe and the US.

The historical investigation and the theorization of the processes of the led non-Western states are crucial to understand their past and present role in the international system as well as their relationship with the current rules and norms of the international system. Examples are, for instance, the works of Shogo Suzuki on China's and Japan's entry in the international society during the late 19th century, that underlines the brutality of the impact with the West, that deeply differs from the rather benevolent portray of the classic English School (Suzuki, 2009). Another path-breaking work from this point of view is Ayse Zarakol's investigation on Turkey, Japan, Russia, and the role of stigma against the outsiders of the international order (Zarakol, 2010).

It is important to underline that the contemporary debate on these issues has moved beyond the pure 'critique' of the mainstream approaches and it has tried to promote a nuanced understanding of the processes that have characterized non-Western states and regions pathways to modernity. To do so, many works in this field have located themselves in a middle ground between critical and mainstream approaches. In particular, while they maintain the necessity to investigate different points of view and perspectives on social and political processes, they keep open the necessity to build a theoretical framework able to 'travel' and elucidate different cases in different regions. This perspective is increasingly relevant for the study of contemporary international politics in East Asia. In particular, it is important to understand how different 
regional and national pathways to modernity shape the current perception of the international order as well as other actors. Each pathway to modernity is crucial to understand how great powers might attempt to reform or contest the regional order. This element is central to understand China's vision of the current regional order and its main normative foundations, such as sovereignty and non-interference (Dian, 2017; Rolland, 2020).

5. States and markets. As Karl Polanyi argued back in 1944, markets do not appear spontaneously when the state retreats, but they are rather embedded in a social, political, and historical context (Polanyi, 1944). As a consequence, understanding the origin and the development of market institutions in non-Western regions is crucial to understand both the development of economic regionalism and regional economic orders and the approach of non-Western nations to global economic governance.

For instance, the Japanese and South Korean approaches to global and regional economic governance are inextricably linked to the rise (and fall) of the developmental state and the dialectic between Western influence and adaptation of foreign models to local interests (Calder, 1991; Johnson, 1995; Woo-Cumings, 1999).

Something similar can be argued for the Chinese case. The study of China's economic history, as well as the analysis of the development of the current 'state capitalist' model and the mutual influence it has had on China's political system, is crucial to understand how Beijing approaches the global and regional economic order (McNally, 2012; Naughton and Tsai, 2015). Yet, relatively few studies have explicitly tried to assess how the consolidation of the state capitalist model, together with the expansion of the Chinese economic presence and influence in Asia and globally, has an impact on the normative and institutional foundations of the international economic order (Dian and Menegazzi, 2020; Breslin, 2021). Nevertheless, this aspect can be considered central for the study of the renegotiation of the international order generated by the rise of China.

6. Globalization and localization of norms. Another key area of research is represented by the relationship between diffusion of global norms and localization of norms at the regional level. As Amitav Acharya has highlighted, in the 'global South', states tend to attach different values and interpret global norms differently, especially those generated by the West. The process of socialization to global norms, and their possible adaptation to local needs and ideas, is strongly influenced by the 'cognitive prior' of any given region or state. Moreover, states often create and consolidate their own rules in order to resist external influence or dominance from great powers (Acharya, 2011a, 2011b).

The investigation of the interaction between global and local norms is still in its infancy, despite the fact that several valuable works have been already published on the topic (Stubbs, 2008; Bellamy and Beeson, 2010; Ban, 2016). Both constructivist approaches and the contemporary English School appear to be particularly equipped for this task, and particularly for the investigation of the global/local interaction, among others, in the fields of diplomacy, human rights protection, the development of markets and capitalism, and diplomatic practices.

This dynamic is crucial for the analysis and the theorization of current processes of contestation of the international order, both at the regional and at the global level. Rising powers in Asia have ceased to be 'norms takers' and have started to promote the forms of regional and global governance informed by their own ideas, norms, models of developments and interests (Foot, 2019). Chinese initiatives such as the Asia Infrastructure and Investment Bank (AIIB) and the Belt and Road Initiative (BRI), or initiatives such as the Regional Comprehensive Economic Partnership (RCEP), rooted in the centrality of ASEAN are just a few examples (Dian and Menegazzi, 2020; Ye, 2020). Understanding both the patterns of resistance to global norms, often associated with liberal and Western ideas and practices, as well as the possibility of 
regionalization and globalization of non-Western norms, represents therefore a key field of enquiry for scholars working at the intersection of IR and AS.

7. Avoiding essentialism. Many IR theorists have tended to essentialize Asian traits and attribute an excessive causal weight on cultural and identity-related variables. An example is the debate on the role of Confucianism as a 'pacifist attitude' and the debate on Confucian peace (Kang, 2010; Kelly, 2012; Larsen, 2013; Phillips, 2018).

On the one hand, it is entirely legitimate to argue that Confucian values and the social structure informed and shaped by those values have played a significant role in East Asian international politics both historically and today. On the other hand, attributing the peacefulness of the Sino-centric order entirely on its Confucian characteristics is probably as accurate as attributing the bellicosity of the early Modern Europe to the Christian features of the European culture.

The essentialization of the Confucian identity is particularly significant in the writings of the Chinese School that tends to portray the PRC as inherently pacifist, reformist, and inclusive, as opposed to a West willing to impose its own interests and values, also through conflict (Zhang, 2013; Hwang, 2021). This process tends to further strengthen the tendency to speak for power, reproducing the same dynamic that many critical and post-colonial theorists denounce in mainstream theories of IR, from the contemporary liberalism to the hegemonic stability theory.

Cooperation and communication between area studies and IR is particularly significant to avoid accepting at face value these assumptions promoted by the Chinese School. IR scholars, particularly on the post-colonial and critical side, should underline how Chinese theories, as much as Western theories, should go through a process of deconstruction and criticism. More attention and dialogue with area scholars and historians of modern and pre-modern Asia would probably help reconsidering the vision of an essentialized China as an ideological construction rather than an accurate historical description that can function as a foundation for a new theoretical approach (Wang, 2010; Pines, 2012; Hui, 2020). ${ }^{6}$

\section{Conclusion}

This article has suggested how cooperation between IR theory and area studies has been and is likely to continue to be, very fruitful as well as necessary for both disciplines. As East Asia and other non-Western regions gain an increasingly central position in international politics as well as in scholarly discussions, IR theory needs to broaden its horizons, both in theoretical and in empirical terms. On the one hand, IR scholars need to recognize that many of the concepts and assumptions on which the discipline have been built upon do not necessarily fit an increasingly plural, globalized, and interconnected world. This does not mean to radically reject the main progresses the discipline has done in the last decades. It rather means considering as relative concepts and assumptions what we previously considered endowed of 'timeless wisdom', and universal validity. It also means seeking to expand the 'sample' of cases, geographically and historically, against which theories are 'tested'.

Overall, testing new limits of theories and concepts does not mean rejecting them altogether, it rather means gaining a better understanding of their validity as heuristic devices. Therefore, concepts such as sovereignty, balance of power, hegemony, and statehood can find different applications in different contexts. They can be extremely useful for most concepts to analyse some regional and international order, while they can be less useful for others.

While critical and post-colonial studies have played an important part in the effort of 'globalizing' the discipline, opening to new voices and perspectives, their effort has largely concentrated

\footnotetext{
${ }^{6}$ IR theorists that have seriously engaged the history of pre-modern China tend to underline the recurrence of conflict both within China and between the Chinese Empire and other political units. An example is Hui (2005).
} 
on the pars denstruens related to the critique of colonialism, racism, and other forms of exploitation. While those are, and remain, legitimate arguments, it is also important to build new theoretical frameworks, or to improve the existing ones, making sure that they are able to provide new insights on international politics of the present and of the past, in various world regions. Very often critical and post-colonial theorists have rejected the concept of generalizability altogether, limiting the possibility of a fruitful debate both with mainstream theories and with area studies.

The final consideration of this paper is related to the idea of building 'national schools' of IR, such as the Chinese School. While the idea of integrating insights from other intellectual traditions is fascinating and entirely legitimate, the actual research project has tended to produce new exceptionalist visions of international politics, or even to offer a new intellectual loudspeaker for power, legitimizing a state's narrative and its foreign policy strategy.

This tendency can also be associated with a sort of 'positive orientalism' by which scholars tend to emphasize the uniqueness of ideas and practices promoted by non-Western and often non-democratic regimes. For instance, concepts such as win-win, new type of great power relations, respect for the principle of non-interference, communitarian spirit, and primacy of the community over the individual can be romanticized as 'uniquely Chinese concepts' or also be understood as elements of a narrative aimed at consolidating non-democratic and authoritarian norms and practices.

Funding. The research received no grants from public, commercial or non-profit funding agency.

Acknowledgements. I would like to thank all the participants of the panel 'Reaching for allies? The dialectics and overlaps between International Relations and Area Studies in the study of politics, security and conflicts' at the SISP conference held in Lecce in September 2019, the two anonymous reviewers, the editor of the journal Filippo Tronconi, the two other co-editors of this Special Issue Silvia D'Amato and Alessandra Russo, as well as all the contributors to this project.

\section{References}

Acharya A (2004) Will Asia's past be its future? International Security 28, 149-164.

Acharya A (2011a) Norm subsidiarity and regional orders: sovereignty, regionalism, and rule-making in the third world. International Studies Quarterly 55, 95-123.

Acharya A (2011b) Whose Ideas Matter?: Agency and Power in Asian Regionalism. Ithaca: Cornell University Press.

Acharya A (2014) Global international relations (IR) and regional worlds. A new agenda for international studies. International Studies Quarterly 58, 647-659.

Acharya A (2016) Advancing global IR: challenges, contentions, and contributions. International Studies Review 18, 4-15.

Acharya A and Buzan B (2007) Why is there no non-Western international relations theory? An introduction. International Relations of the Asia-Pacific 7, 287-312.

Acharya A and Buzan B (2019) The Making of Global International Relations. Cambridge: Cambridge University Press.

Allison G (2017) Destined for War: Can America and China Escape Thucydides's Trap?. Boston: Houghton Mifflin Harcourt.

Ban C (2016) Ruling Ideas: How Global Neoliberalism Goes Local. Oxford: Oxford University Press.

Bellamy AJ and Beeson M (2010) The responsibility to protect in Southeast Asia: can ASEAN reconcile humanitarianism and sovereignty? Asian Security 6, 262-279.

Berg M (2013) Writing the History of the Global. Oxford: Oxford University Press.

Bose S and Horizons AH (2006) The Indian Ocean in the Age of Global Empire. Cambridge: Harvard University Press.

Breslin S (2021) China Risen?: Studying Chinese Global Power. Bristol: University of Bristol Press.

Bull H and Watson A (1984) The Expansion of International Society. Oxford: Clarendon Press.

Buzan B and Lawson G (2014) Rethinking benchmark dates in international relations. European Journal of International Relations 20, 437-462.

Buzan B and Lawson G (2015) The Global Transformation: History, Modernity and the Making of International Relations. Cambridge: Cambridge University Press.

Calder KE (1991) Crisis and Compensation: Public Policy and Political Stability in Japan, 1949-1986. Princeton: Princeton University Press.

Callahan WA (2008) Chinese visions of world order: post hegemonic or a new hegemony? International Studies Review 10, 749-761. 
Callahan WA (2015) History, tradition and the China dream: socialist modernization in the World of Great Harmony. Journal of Contemporary China 24, 983-1001.

Chakrabarty D (2000) Provincializing Europe: Postcolonial Thought and Historical Difference. Princeton: Princeton University Press.

Cox RW (1983) Gramsci, hegemony and international relations: an essay in method. Millennium 12, 162-175.

Cox RW (1987) Production, Power, and World Order: Social Forces in the Making of History. New York: Columbia University Press.

Cox M (2012) Power shifts, economic change and the decline of the West? International Relations 26, 369-388.

Dian M (2017) Contested Memories in Chinese and Japanese Foreign Policy. Oxford: Elsevier.

Dian M and Meijer H (2020) Networking hegemony. Alliance dynamics in East Asia. International Politics 57, $131-149$.

Dian M and Menegazzi S (2018) New Regional Initiatives in China's Foreign Policy: The Incoming Pluralism of Global Governance. Basingstoke: Palgrave Macmillan.

Fairbank JK and Chen TT (1968) In the Chinese World Order: Traditional China's Foreign Relations. Cambridge: Harvard University Press.

Foot R (2020) China's rise and US hegemony: renegotiating the regional order in east Asia. International Politics 57, 150165.

Friedberg A (2000) Will Europe's past be Asia's future. Survival 42, 147-160.

Gill S (ed) (1993) Gramsci, Historical Materialism and International Relations. Cambridge: Cambridge University Press.

Gilpin RG (1984) The richness of the tradition of political realism. International Organization 38, $287-304$.

Goh E (2019) US dominance and American bias in international relations scholarship: a view from the outside. Journal of Global Security Studies 4, 402-410.

Hagström L and Nordin AH (2019) China's 'politics of harmony' and the quest for soft power in international politics. International Studies Review 22, 507-525.

Hobson JM (2012) The Eurocentric Conception of World Politics: Western International Theory, 1760-2010. Cambridge: Cambridge University Press.

Hobson JM and Sajed A (2017) Navigating beyond the Eurofetishist Frontier of critical IR theory: exploring the complex landscapes of non-Western agency. International Studies Review 19, 547-572.

Hopf T (2013) Common-sense constructivism and hegemony in world politics. International Organization 67, $317-354$.

Hui VT (2005) War and State Formation in Ancient China and Early Modern Europe. Cambridge: Cambridge University Press.

Hui VT (2020) Evolution of Confucianism: construction of Confucian pacifism and Confucian autocracy in Chinese history. In Bondarenko DM and Kowalewski SA (eds), The Evolution of Social Institutions. London: Springer, pp. 205-224.

Hurrell A (2016) Beyond critique: how to study Global IR? International Studies Review 18, 149-151.

Hutchings K (2007) Happy anniversary! Time and critique in international relations theory. Review of International Studies 33, 71-89.

Hwang YJ (2021) Reappraising the Chinese school of international relations: a postcolonial perspective. Review of International Studies 47, 311-330.

Ikenberry GJ and Nexon DH (2019) Hegemony studies 3.0: the dynamics of hegemonic orders. Security Studies 28, 395-421.

Johnson C (1995) Japan, Who Governs? The Rise of the Developmental State. New York: WW Norton \& Company.

Johnston AI (2012) What (if anything) does East Asia tell us about international relations theory? Annual Review of Political Science 15, 53-78.

Kang DC (2003) Getting Asia wrong: the need for new analytical frameworks. International Security 27, 57-85.

Kang DC (2010) Hierarchy and legitimacy in international systems: the tribute system in early modern East Asia. Security Studies 19, 591-622.

Kang DC (2017) American Grand Strategy and East Asian Security in the Twenty-First Century. Cambridge: Cambridge University Press.

Kang DC and Lin AYT (2019) US bias in the study of Asian security: using Europe to study Asia. Journal of Global Security Studies 4, 393-401.

Kayaoglu T (2010) Westphalian Eurocentrism in international relations theory. International Studies Review 12, $193-217$.

Kelly RE (2012) A 'Confucian long peace' in pre-Western East Asia? European Journal of International Relations 18, 407430.

Larsen KW (2013) Comforting fictions: the tribute system, the Westphalian order, and Sino-Korean relations. Journal of East Asian Studies 13, 233-257.

Li M (2019) China's economic power in Asia: the belt and road initiative and the local Guangxi government's role. Asian Perspective 43, 273-295.

Ling LH (2014) The Dao of World Politics: Towards a Post-Westphalian, Worldist International Relations. New York: Routledge. 
Ling LH (2018) What's in a name? A critical interrogation of the Chinese school of IR. In Zhang Y and Chang TC (eds), Constructing a Chinese School of International Relations: Ongoing Debates and Sociological Realities. London: Routledge, pp. 17-34.

Liu F and Liu R (2019) China, the United States, and order transition in East Asia: an economy-security Nexus approach. The Pacific Review 32, 972-995.

Loke B (2021) The United States, China, and the politics of hegemonic ordering in East Asia. International Studies Review. Online first, 1-24. https://doi.org/10.1093/isr/viaa096.

MacDonald PK and Lake DA (2008) The role of hierarchy in international politics. International Security 32, $171-180$.

Mattern JB and Zarakol A (2016) Hierarchies in world politics. International Organization 70, 623-654.

McConaughey M, Musgrave P and Nexon DH (2018) Beyond anarchy: logics of political organization, hierarchy, and international structure. International Theory 10, 181-218.

McNally CA (2012) Sino-capitalism: China's re-emergence and the international political economy. World Politics 64, 741776.

Naughton B and Tsai KS (eds) (2015) State Capitalism, Institutional Adaptation, and the Chinese Miracle. Cambridge: Cambridge University Press.

Neufeld MA (1995) The Restructuring of International Relations Theory. Cambridge: Cambridge University Press.

Nordin AH (2016) China's International Relations and Harmonious World: Time, Space and Multiplicity in World Politics. London: Routledge.

Osiander A (2001) Sovereignty, international relations, and the Westphalian myth. International Organization 55, $251-287$.

Perez Garcia M and De Sousa L (2018) Global History and New Polycentric Approaches: Europe, Asia and the Americas in a World Network System. Basingstoke: Palgrave Macmillan.

Persaud R and Sajed A (2018) Race, Gender, and Culture in International Relations: Postcolonial Perspectives. London: Routledge.

Phillips A (2016a) Global IR meets global history: sovereignty, modernity, and the international system's expansion in the Indian Ocean Region. International Studies Review 18, 62-77.

Phillips A (2016b) The global transformation, multiple early modernities, and international systems change. International Theory 8, 481-491.

Phillips A (2018) Contesting the Confucian peace: civilization, barbarism and international hierarchy in East Asia. European Journal of International Relations 24, 740-764.

Phillips A and Sharman JC (2015) International Order in Diversity: War, Trade and Rule in the Indian Ocean. Cambridge: Cambridge University Press.

Pines Y (2012) The Everlasting Empire: The Political Culture of Ancient China and Its Imperial Legacy. Princeton: Princeton University Press.

Polanyi K (1944) The Great Transformation. Boston: Beacon Press.

Pomeranz K (2000) The Great Divergence. Princeton: Princeton University Press.

Qin Y (2006) A Chinese school of international relations theory: possibility and inevitability. World Economics and Politics 3, 7-13.

Qin Y (2007) Why is there no Chinese international relations theory? International Relations of the Asia-Pacific 7, 313-340.

Qin Y (2010) International society as a process: institutions, identities, and China's peaceful rise. The Chinese Journal of International Politics 3, 129-153.

Qin Y (2011) Rule, rules, and relations: towards a synthetic approach to governance. The Chinese Journal of International Politics 4, 117-145.

Qin Y (2018) A Relational Theory of World Politics. Cambridge: Cambridge University Press.

Rolland N (2020) China's Vision for a New World Order. Washington: National Bureau of Asian Research.

Sajed A (2013) Postcolonial Encounters in International Relations: The Politics of Transgression in the Maghreb. London: Routledge.

Sartori G (1970) Concept misformation in comparative politics. The American Political Science Review 64, $1033-1053$.

Seth S (2009) Historical sociology and postcolonial theory: two strategies for challenging Eurocentrism. International Political Sociology 3, 334-338.

Seth S (2011) Postcolonial theory and the critique of international relations. Millennium 40, 167-183.

Stubbs R (2008) The ASEAN alternative? Ideas, institutions and the challenge to 'global' governance. The Pacific Review 21, 451-468.

Suzuki S (2009) Civilization and Empire: China and Japan's Encounter with European International Society. London: Routledge.

Teschke B (2003) The Myth of 1648: Class, Geopolitics, and the Making of Modern International Relations. London: Verso.

Tickner A (2003) Seeing IR differently: notes from the Third World. Millennium 32, 295-324.

Tickner AB (2013) Core, periphery and (neo)imperialist international relations. European Journal of International Relations 19, 627-646.

Veevers D (2020) The Origins of the British Empire in Asia, 1600-1750. Cambridge: Cambridge University Press. 
Vezirgiannidou SE (2013) The United States and rising powers in a post-hegemonic global order. International Affairs 89 , 635-651.

Waltz KN (1979) Theory of International Politics. New York: Waveland Press.

Wang YK (2010) Harmony and War: Confucian Culture and Chinese Power Politics. New York: Columbia University Press.

Wang J and Buzan B (2014) The English and Chinese schools of international relations: comparisons and lessons. Chinese Journal of International Politics 7, 1-46.

Wendt A (1999) Social Theory of International Politics. Cambridge: Cambridge University Press.

Williams J (2021) English School-'Chinese IR' engagements: order, harmony, and the limits of elitism in global IR. The Chinese Journal of International Politics 14, 127-157.

Woo-Cumings M (ed) (1999) The Developmental State. Ithaca: Cornell University Press.

Xi J (2015) Working together to forge a new partnership of win win cooperation and create a community of shared future for the human kind. Speech at the UN General Assembly. Available at https://www.fmprc.gov.cn/mfa_eng/topics_665678/ xjpdmgjxgsfwbcxlhgcl70znxlfh/t1305051.shtml.

Yan X (2011) Ancient Chinese Thought, Modern Chinese Power. Princeton: Princeton University Press.

Yan X (2014) From keeping a low profile to striving for achievement. Chinese Journal of International Politics 7, $153-184$.

Yan X (2019) Leadership and the Rise of Great Powers. Princeton: Princeton University Press.

Ye M (2020) The Belt Road and Beyond: State-Mobilized Globalization in China: 1998-2018. Cambridge: Cambridge University Press.

Zarakol A (2010) After Defeat: How the East Learned to Live with the West. Cambridge: Cambridge University Press.

Zhang F (2012) The Tsinghua approach and the inception of Chinese theories of international relations. The Chinese Journal of International Politics 5, 73-102.

Zhang F (2013) The rise of Chinese exceptionalism in international relations. European Journal of International Relations 19, 305-328.

Zhang Y and Buzan B (2012) The tributary system as international society in theory and practice. The Chinese Journal of International Politics 5, 3-36.

Zhao T (2006) Rethinking empire from a Chinese concept 'All-under-Heaven' (Tian-xia). Social Identities 12, $29-41$.

Zhao T (2009) A political world philosophy in terms of all-under-heaven (Tian-xia). Diogenes 221, 5-18.

Zhao T (2013) The China Dream in question. Harvard-Yenching Institute Working Paper Series.

Cite this article: Dian M (2022). The rise of China between Global IR and area studies: an agenda for cooperation. Italian Political Science Review/Rivista Italiana di Scienza Politica 52, 252-267. https://doi.org/10.1017/ipo.2021.31 